\title{
Lovastatin Increases Arachidonic Acid Levels and Stimulates Thromboxane Synthesis in Human Liver and Monocytic Cell Lines
}

\author{
N. Hrboticky, L. Tang, B. Zimmer, I. Lux, and P. C. Weber \\ Institut für Prophylaxe und Epidemiologie der Kreislaufkrankheiten, Universität München, 80336 München, Germany
}

\begin{abstract}
The effect of lovastatin (LOV), the inhibitor of 3-hydroxy-3methyl-glutaryl coenzyme $A$ reductase, on linoleic acid (LA, 18:2n-6) metabolism was examined in human monocytic Mono Mac 6 (MM6) and hepatoma Hep G2 cells. The desaturation of LA was examined after $\operatorname{LOV}(72 \mathrm{~h}, 10 \mu \mathrm{M})$ or dimethylsulfoxide ( LOV carrier, $<0.1 \%$ ) and $\left[{ }^{14} \mathrm{C}\right] \mathrm{LA}$ (last $18 \mathrm{~h}, 0.3 \mu \mathrm{Ci}$, $5 \mu \mathrm{M}$ ). In both cell lines, LOV reduced the percentage of ${ }^{14} \mathrm{C}$ label associated with $L A$ and increased the percentage of label in the 20:4n-6 and the 22:5n-6 fractions. In Hep G2 but not MM6 cells, this effect was fully reversible by means of coincubation with mevalonic acid $(500 \mu \mathrm{M})$, but not with cholesterol or lipoproteins. In both cell lines, the LOV-mediated increase in LA desaturation resulted in dose-dependent reductions of LA and elevations of $\mathrm{AA}$ in cellular phospholipids. The lipids secreted by LOV-treated Hep G2 cells were also enriched in arachidonic acid (AA). In the MM6 cells, LOV increased release of thromboxane upon stimulation with the calcium ionophore A23187. In summary, our findings of higher LA desaturation and $A A$ enrichment of lipids secreted by the Hep G2 cells suggest that LOV treatment may increase the delivery of AA from the liver to extrahepatic tissues. The changes in membrane fatty acid composition can influence a variety of cellular functions, such as eicosanoid synthesis in monocytic cells. The mechanism appears to be related to the reduced availability of intermediates of cholesterogenesis. (J. Clin. Invest. 1994. 93:195-203.) Key words: fatty acids - 3-hydroxy-3-methyl coenzyme A reductase inhibitor • lipoproteins • mevalonate • thromboxane
\end{abstract}

\section{Introduction}

Inhibitors of 3-hydroxy-3-methyl-glutaryl CoA(HMGCoA $)^{1}$ reductase, such as (LOV), are widely used in the treatment of hypercholesterolemia. They suppress the early conversion step of HMGCoA to mevalonate (MVA) and thus the subsequent synthesis of cholesterol and its precursors. Their main site of action is the liver, where inhibition of cholesterol synthesis leads to the desired up-regulation of LDL receptor-mediated

Address correspondence to Dr. N. Hrboticky, Institut für Prophylaxe und Epidemiologie der Kreislaufkrankheiten, Pettenkoferstrasse 9, 80336 München, Germany.

Received for publication 23 November 1992 and in revised form 20 July 1993

1. Abbreviations used in this paper: HMGCoA, 3-hydroxy-3-methylglutaryl coenzyme A; LA, linoleic acid; LOV, lovastatin; MM6, Mono Mac 6; MVA, mevalonic acid; PUFA, polyunsaturated fatty acids.

J. Clin. Invest.

(c) The American Society for Clinical Investigation, Inc.

0021-9738/94/01/0195/09 \$2.00

Volume 93, January 1994, 195-203 removal of plasma cholesterol. The inhibition of intracellular cholesterol synthesis, however, may be associated with an alteration of a variety of other cellular functions. The cholesterol content of membranes plays an essential role in membrane integrity and regulation of membrane-mediated processes (1, 2 ). Furthermore, the involvement of many cholesterol precursors, such as farnesyl or geranyl pyrophosphates are under intensive investigation regarding their role in multiple facets of cellular function $(3,4)$.

A number of clinical investigations (5-7) show that the use of HMGCoA reductase inhibitors can modify plasma and erythrocyte long-chain polyunsaturated fatty acids (PUFA). Microsomal acyl CoA desaturases, the rate-determining enzymes of PUFA synthesis (Fig. 1) are known to be influenced by microsomal cholesterol composition $(1,8-10)$. Furthermore, changes in desaturase activity may occur during cellular events such as differentiation $(11,12)$ or transformation (13), processes potentially influenced by cholesterol or its precursors. Modification of fatty acid desaturase activity leads to changes in eicosanoid synthesis (10), presumably by influencing eicosanoid precursor availability.

The present study examined the effect of LOV on linoleic acid (LA) metabolism, and cellular phospholipid fatty acid composition in human hepatoma Hep G2 (14) and human monocytic Mono Mac 6 (MM6) (15) cells. Two functional consequences, the fatty acid composition of lipids secreted by the Hep G2 cells and thromboxane release in ionophore A23187-stimulated MM6 cells were also investigated.

\section{Methods}

Materials. LOV was a kind gift of Dr. A. W. Alberts from Merck Sharp \& Dohme (Rahway, NJ). LA (18:2n-6), MVA lactone, cholesterol, BSA (essentially fatty acid free, A6003), and cell culture media and ingredients were from Sigma Chemical Co. (Munich, FRG). Organic solvents, DMSO, silica 60 TLC (no. 5721), and HPTLC (no. 5641) plates were purchased from E. Merck (Darmstadt, FRG). Bond-Elut solid-phase extraction columns ( $\mathrm{NH}_{2}$-aminopropyl, 1-ml bed volume) were from Baker Chemical Co. (no. 7088-1, Denveter, Netherlands) and $\left[1-{ }^{14} \mathrm{C}\right] \mathrm{LA}$ ( $\mathrm{sp}$ act $1.85-2.26 \mathrm{~Bq} / \mathrm{mmol}$ ) was from Amersham (Braunschweig, FRG).

Cell culture. MM6 cells, obtained from Dr. H.-W. E. Ziegler-Heitbrock (Institute of Immunology, University of Munich), were grown in stationary suspension in $2-\mathrm{ml}$ culture well dishes at $37^{\circ} \mathrm{C}$ in a humidified atmosphere of $5 \% \mathrm{CO}_{2}$ and $95 \%$ air and were split every 3-4 d. The medium, RPMI 1640 supplemented with $10 \%$ FCS, nonessential amino acids $(0.1 \mathrm{mM})$, oxaloacetate $(1 \mathrm{mM})$, pyruvate $(1 \mathrm{mM})$, penicillin-streptomycin (1\%), L-glutamine $(2 \mathrm{mM})$, was ultrafiltered through a Gambro 200 column (Gambro, Hechingen, FRG) to eliminate LPS. Hep G2 cells (American Type Culture Collection, Rockville, MD) were grown in 15-ml flasks in DME medium (Sigma, D5405) supplemented with $10 \%$ FCS, nonessential amino acids ( $1 \mathrm{mM}$ ), and L-glutamine ( $2 \mathrm{mM}$ ) and were passaged ( $1: 4)$ once a week with trypsinEDTA.

Preparation of albumin-bound LA. LA was dissolved in ethanol and converted to its anion by precipitation with $0.5 \mathrm{~N} \mathrm{KOH}$. Ethanol was 


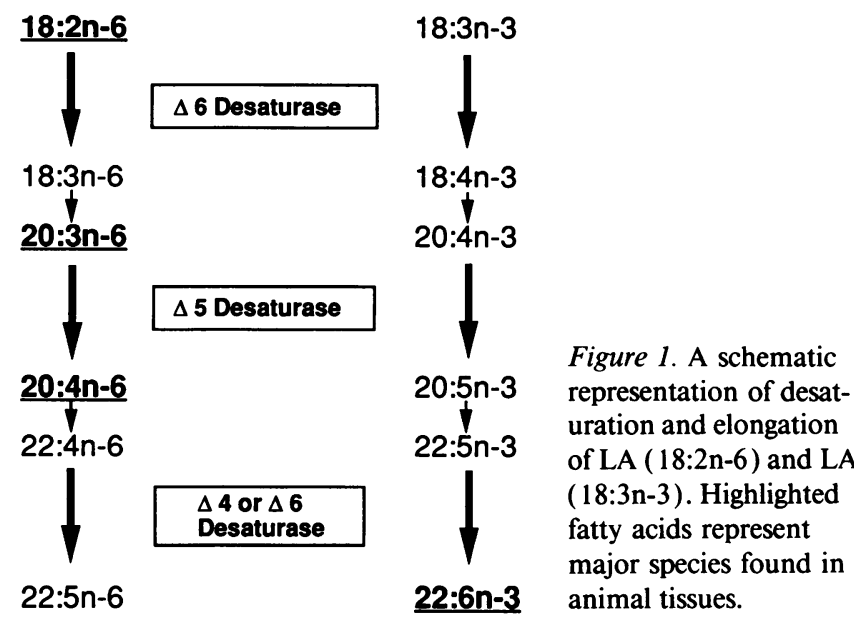

evaporated under $\mathrm{N}_{2}$ and the salt was immediately reconstituted with $2.5 \mathrm{mM}$ BSA dissolved in RPMI 1640 to yield a $5 \mathrm{mM}$ fatty acid solution. The $\mathrm{pH}$ was adjusted to 7.4 with $1 \mathrm{~N} \mathrm{NaOH}$ and aliquots were stored in liquid $\mathrm{N}_{2}$.

Preparation of lipoproteins. LDL was isolated from normolipemic fasting plasma in the density interval $1.021-1.063$ by sequential preparative ultracentrifugation and dialyzed against 20 liters of buffer containing $9 \mathrm{~g} /$ liters $\mathrm{Na} \mathrm{Cl}, 0.09 \mathrm{~g} /$ liters EDTA, and $0.05 \mathrm{~g} /$ liters chloramphenicol, pH 7.4. Acetyl LDL was prepared as described in Basu et al. (16), washed, and concentrated in the above buffer by means of Centricon filters (CF25, Amicon, Witten, FRG). The extent of LDL acetylation was assessed by agarose-gel electrophoresis (Ciba Corning, Medfield, MA). Protein content was determined (17), and lipoproteins were filter-sterilized $(0.22 \mu \mathrm{m})$, stored at $4^{\circ} \mathrm{C}$, and used within $1 \mathrm{mo}$.

Determination of phospholipid fatty acids. Newly passaged MM6 $\left(0.2 \times 10^{6} \mathrm{cells} / \mathrm{ml}\right)$ in the above medium with $10 \%$ FCS and Hep G2 cells $72 \mathrm{~h}$ after passage and given fresh DME medium with 10\% delipidated serum (CPSR-1, Sigma Chemical Co.) were treated with LOV (dissolved in DMSO) or DMSO alone $(\leq 0.1 \%)$ for $72 \mathrm{~h}$. Albuminbound LA was added for the last $24 \mathrm{~h}$ or for $72 \mathrm{~h}$ to the MM6 cells ( 10 $\mu \mathrm{M})$ and Hep G2 cells ( $40 \mu \mathrm{M})$, respectively. After incubation, cells were washed $(3 \times 5 \mathrm{ml} \mathrm{NaCl} 0.9 \%)$ and cellular lipids were extracted with chloroform/methanol $(2: 1)$, containing butylated hydroxytoluene. Phospholipids were separated on aminopropyl-bonded phase Bond-Elut columns (18). The phospholipid eluate was transesterified with methanolic $\mathrm{HCl}\left(90^{\circ} \mathrm{C}, 1 \mathrm{~h}\right)$ in the presence of $17: 0$ as internal standard, fatty acid methyl esters were recovered in petroleum benzene and quantified with a Hewlett-Packard Co. (Palo Alto, CA) model $5890 \mathrm{~A}$ gas chromatograph, using a $0.25-\mathrm{mm} \times 30-\mathrm{m} \mathrm{DB}-225$ fused silica capillary column. The carrier gas was helium at a flow rate of 5 $\mathrm{ml} / \mathrm{min}$. Injection and ionization temperatures were $200^{\circ} \mathrm{C}$ and $250^{\circ} \mathrm{C}$, respectively.

Determination of LA desaturation. Freshly passaged MM6 cells $\left(0.2 \times 10^{6}\right.$ cells $\left./ \mathrm{mL}\right)$ and Hep G2 cells ( $1: 4$ or $1: 3$ split) were treated with LOV, MVA, cholesterol, or lipoproteins as described later in detail. At $52 \mathrm{~h}$, cells either given fresh serum-free media containing $0.025 \%$ BSA or left in the original $10 \%$ FCS media, were incubated with $0.3 \mu \mathrm{Ci}(5 \mu \mathrm{M}$, dissolved in ethanol, final concentration $0.15 \%$ ) $\left[{ }^{14} \mathrm{C}\right] 18: 2 \mathrm{n}-6$ for the last $18 \mathrm{~h}$. At $72 \mathrm{~h}$, cells were washed in PBS, four times with and without $0.1 \%$ BSA. The radioactivity in medium and washed cell aliquots was measured to estimate the incorporation of ${ }^{14} \mathrm{C}$ label. Total cellular lipids were extracted with hexane/isopropanol (3:2, vol/vol, containing butylated hydroxytoluene) and transesterified with methanolic $\mathrm{HCl}\left(90^{\circ} \mathrm{C}, 1 \mathrm{~h}\right)$. Fatty acid methyl esters were separated on HPTLC plates impregnated with $20 \%$ of aqueous $\mathrm{AgNO}_{3}$ or $3 \% \mathrm{AgNO}_{3}$ in $93 \%$ methanol (19). The percent distribution of ${ }^{14} \mathrm{C}$ label in fatty acids with two to five double bonds was quantified by means of a TLC-linear radioactivity scanner (Berthold, Munich, FRG). $R_{\mathrm{f}}$ values were determined using both radioactive and cold standards. For the determination of ${ }^{14} \mathrm{C}$ label distribution among lipid subclasses, total lipid was extracted as above and separated into total phospholipid, triglyceride, free fatty acid, and cholesterol ester on aminopropyl-bonded phase Bond-Elut columns (18) or on silica TLC plates developed in petroleum ether, diethyl ether, and acetic acid $(85: 15: 3, \mathrm{vol} / \mathrm{vol} / \mathrm{vol})$. The radioactivity in isolated fractions was measured by means of a liquid scintillation counter (model LS 5801; Beckman Instruments, Munich, FRG).

Determination of fatty acid composition of lipids secreted by Hep G2 cells. Freshly passaged Hep G2 cells, grown in DME with $10 \%$ FCS, were treated with LOV $0.04-10 \mu \mathrm{M}$ or DMSO (5-6 175- $\mathrm{cm}^{2}$ flasks per treatment) for a total of $8 \mathrm{~d}$. On day 4 , cells were given fresh growth medium containing $10 \mu \mathrm{M}$ albumin-bound LA. On day 6, growth medium was removed and cells were washed three times with $30 \mathrm{ml}$ of Dulbecco's PBS and once with serum-free DME. After washing, $30 \mathrm{ml}$ of fresh serum-free DME was added and harvested after $24 \mathrm{~h}$. This procedure was repeated on day 7 . The harvested medium was supplemented with EDTA $(1 \mathrm{mg} / \mathrm{ml})$ and gentamycin sulfate $(0.1 \mathrm{mg} / \mathrm{ml})$, centrifuged at $1,000 \mathrm{~g}$ for $30 \mathrm{~min}$ at $4^{\circ} \mathrm{C}$ to remove cell debris, and stored at $4^{\circ} \mathrm{C}$. Media from the two harvests were pooled and concentrated to minimal volumes by ultrafiltration (Amicon stirred cell, PM30 membranes). Concentrates were lyophilized and total lipids were extracted with chloroform/methanol (2:1). Phospholipid, triglyceride, and cholesterol ester fractions were separated on aminopropyl columns (18), and fatty acids were quantified as described above.

Determination of thromboxane release. Freshly passaged MM6 cells were incubated with LOV, LA, MVA, and lipoproteins as described later in detail. Medium was removed after centrifugation ( 800 $\mathrm{rpm} \times 5 \mathrm{~min}$ ) and cells were resuspended at $10^{6} \mathrm{cells} / \mathrm{ml}$ in a buffer containing $20 \mathrm{mM}$ Hepes, $120 \mathrm{mM} \mathrm{NaCl}, 2.7 \mathrm{mM} \mathrm{KCl}, 1.4 \mathrm{mM}$ $\mathrm{MgSO}_{4}, 1 \mathrm{mM} \mathrm{CaCl}, 1.4 \mathrm{mM} \mathrm{KH}_{2} \mathrm{PO}_{4}, 25 \mathrm{mM} \mathrm{NaHCO}$, and 10 $\mathrm{mM}$ glucose, $\mathrm{pH} \mathrm{7.4}$. Cells were then stimulated $\left(37^{\circ} \mathrm{C}, 5 \mathrm{~min}\right)$ with ionophore A23187 ( $1 \mu \mathrm{M}$ in DMSO) or DMSO alone (final concentration $\leq 0.1 \%$ ). Stimulation was terminated at $4^{\circ} \mathrm{C}$, and thromboxane release was determined in 50- $\mu \mathrm{l}$ aliquots of supernatant using a highly specific and sensitive antiserum against $\mathrm{TXB}_{2}$ (gift of Dr. J. Levine, Brandeis University, Waltham, MA) and $\left[{ }^{3} \mathrm{H}\right] \mathrm{TXB}_{2}$ as a tracer (20).

Determination of cellular protein and lipids. Aliquots of Hep G2 and MM6 cells were washed and extracted with hexane/isopropanol (3:2) as described above. Total cellular cholesterol (21), phospholipid (22), and triglyceride (kit no 470694, Boehringer Mannheim GmbH, Mannheim) levels were determined in aliquots of the total lipid extract. Protein of extracted cell pellets was measured as in Rodriguez-Vico et al. (23).

Statistics. Unless otherwise stated, results are expressed as means \pm SEM. Statistical significance was assessed by means of Student's $t$ test for paired and unpaired data and analysis of variance as appropriate.

\section{Results}

LOV effects on cellular phospholipid fatty acid composition. In MM6 cells supplemented with $\operatorname{LA}(10 \mu \mathrm{M}), \operatorname{LOV}(0.4,4,10$, and $20 \mu \mathrm{M}$ ) produced a statistically significant, dose-dependent decrease in cellular phospholipid 18:2n-6 content $(10.5 \pm 0.8 \%$ in control cells vs. $5.6 \pm 0.5 \%$ in cells treated with $20 \mu \mathrm{M}$ LOV) (Table I). In contrast, the relative AA content was increased from $9.7 \pm 0.5 \%$ in control cells to $12.9 \pm 0.3 \%$ and $14.9 \pm 0.4 \%$ in cells treated with 10 and $20 \mu \mathrm{M}$ LOV, respectively (Table I). At the two highest LOV doses, significant increases in the minor longer-chain, more desaturated derivatives of AA, 22:4n-6 and 22:5n-6, were also observed.

Similarly, in Hep G2 cells supplemented with $40 \mu \mathrm{M}$ of BSA-bound LA, LOV at doses ranging from 0.4 to $40 \mu \mathrm{M}$ reduced the relative phospholipid 18:2n-6 content ( $12.5 \pm 0.1 \%$ control cells to $9.4 \pm 0.4 \% 40 \mu \mathrm{M} \mathrm{LOV}$ ) (Table II). The relative 
Table I. Phospholipid Fatty Acid Composition of MMG Cells Incubated with LOV and LA

\begin{tabular}{|c|c|c|c|c|c|}
\hline & \multirow[b]{2}{*}{ DMSO } & \multicolumn{4}{|c|}{$\operatorname{LOV}(\mu \mathrm{M})$} \\
\hline & & 0.4 & 4 & 10 & 20 \\
\hline \multicolumn{6}{|l|}{ Saturated } \\
\hline $\operatorname{cl6:0}$ & $40.8 \pm 0.8$ & $41.3 \pm 1.0$ & $41.7 \pm 1.0$ & $41.0 \pm 1.0$ & $39.4 \pm 0.8$ \\
\hline $\mathrm{cl} 18: 0$ & $8.1 \pm 0.4$ & $7.9 \pm 0.3$ & $8.6 \pm 0.6$ & $7.6 \pm 0.4$ & $8.1 \pm 0.6$ \\
\hline \multicolumn{6}{|l|}{ Monoene } \\
\hline c18:1 $1^{\ddagger}$ & $23.4 \pm 0.8$ & $22.8 \pm 0.8$ & $22.5 \pm 0.7$ & $23.6 \pm 1.0$ & $22.4 \pm 1.0$ \\
\hline \multicolumn{6}{|c|}{ Polyunsaturated } \\
\hline \multicolumn{6}{|c|}{ n-6 series } \\
\hline $18: 2$ & $10.5 \pm 0.8$ & $9.0 \pm 0.5$ & $7.7 \pm 0.5^{*}$ & $6.4 \pm 0.5^{*}$ & $5.6 \pm 0.5^{*}$ \\
\hline $20: 3$ & $1.8 \pm 0.1$ & $1.9 \pm 0.1$ & $2.0 \pm 0.1$ & $2.0 \pm 0.1$ & $2.1 \pm 0.2$ \\
\hline $20: 4$ & $9.7 \pm 0.5$ & $11.2 \pm 0.4$ & $11.7 \pm 0.5$ & $12.9 \pm 0.3^{*}$ & $14.9 \pm 0.4^{*}$ \\
\hline $22: 4$ & $0.6 \pm 0.06$ & $0.7 \pm 0.07$ & $0.9 \pm 0.07$ & $1.2 \pm 0.10^{*}$ & $1.8 \pm 0.14^{*}$ \\
\hline $22: 5$ & $0.4 \pm 0.05$ & $0.4 \pm 0.04$ & $0.5 \pm 0.05$ & $0.6 \pm 0.1$ & $0.7 \pm 0.05^{*}$ \\
\hline \multicolumn{6}{|c|}{ n-3 series } \\
\hline $20: 5$ & $0.7 \pm 0.03$ & $0.7 \pm 0.03$ & $0.7 \pm 0.03$ & $0.6 \pm 0.04$ & $0.6 \pm 0.05$ \\
\hline $22: 5$ & $1.3 \pm 0.2$ & $1.3 \pm 0.1$ & $1.3 \pm 0.1$ & $1.5 \pm 0.2$ & $1.6 \pm 0.2$ \\
\hline $22: 6$ & $2.5 \pm 0.2$ & $2.5 \pm 0.1$ & $2.5 \pm 0.1$ & $2.8 \pm 0.3$ & $2.9 \pm 0.3$ \\
\hline
\end{tabular}

Freshly passaged MM6 cells were incubated with $0.4-20 \mu \mathrm{M}$ LOV or DMSO $\leq 0.1 \%$ for $72 \mathrm{~h}$ and $10 \mu \mathrm{M}$ LA for the last $24 \mathrm{~h}$. Cells were extracted, phospholipids separated and fatty acid methyl esters quantitated as described in Methods. Values $(\mu \mathrm{M})$ are means \pm 1 SEM from five to eight experiments. * Value is different from DMSO control using one-factor ANOVA with Sheffe $F$ test for differences between means. ${ }^{*}$ Value represents sum of $18: 1$ isomers.

content of $20: 4 \mathrm{n}-6$ was increased from $6.0 \pm 0.3 \%$ in control cells to $7.3 \pm 0.3 \%, 7.7 \pm 0.1 \%$, and $7.3 \pm 0.3 \%$ in cells treated with 4,10 , and $40 \mu \mathrm{M}$ LOV, respectively (Table II).

Lovastatin had no effect on the relative content of phospholipid saturated and monoene fatty acids in the two cell lines studied ( Tables I and II). The levels of n-3 fatty acids were also not altered by LOV, most likely due to the low levels of the precursor (18:3n-3) present.

The effect of LOV ( $10 \mu \mathrm{M}, 72 \mathrm{~h}$ ) on cellular phospholipid composition was also examined in Hep G2 cells coincubated with LDL ( $100 \mu \mathrm{g} / \mathrm{ml}$, last $24 \mathrm{~h})$. LDL incubation produced a large increase in LA content in cellular phospholipids

Table II. Phospholipid Fatty Acid Composition of Hep G2 Cells Incubated with LOV and LA

\begin{tabular}{|c|c|c|c|c|c|c|}
\hline & \multirow{2}{*}{$\begin{array}{l}\text { DMSO } \\
(0.025 \%)\end{array}$} & \multicolumn{5}{|c|}{$\operatorname{LOV}(\mu \mathrm{M})$} \\
\hline & & 0.04 & 0.4 & 4 & 10 & 40 \\
\hline \multicolumn{7}{|l|}{ Saturated } \\
\hline $\mathrm{cl} 16: 0$ & $32.4 \pm 2.2$ & $31.4 \pm 1.3$ & $32.3 \pm 1.4$ & $31.8 \pm 1.2$ & $31.1 \pm 1.1$ & $30.6 \pm 0.9$ \\
\hline c18:0 & $6.5 \pm 0.3$ & $6.2 \pm 0.5$ & $6.6 \pm 0.6$ & $7.4 \pm 1.3$ & $6.5 \pm 0.4$ & $6.7 \pm 0.3$ \\
\hline \multicolumn{7}{|l|}{ Monoene } \\
\hline $\operatorname{cl} 8: 1^{\ddagger}$ & $40.5 \pm 1.0$ & $41.2 \pm 1.0$ & $40.3 \pm 1.9$ & $40.7 \pm 1.8$ & $42.4 \pm 1.2$ & $42.5 \pm 0.9$ \\
\hline \multicolumn{7}{|c|}{ Polyunsaturated } \\
\hline \multicolumn{7}{|c|}{ n-6 series } \\
\hline $18: 2$ & $12.5 \pm 0.1$ & $11.9 \pm 0.1$ & $10.5 \pm 0.1^{*}$ & $9.6 \pm 0.3^{*}$ & $8.9 \pm 0.1^{*}$ & $9.4 \pm 0.4^{*}$ \\
\hline $20: 3$ & 1.8 & 1.9 & 2.0 & 2.2 & 2.2 & 2.7 \\
\hline $20: 4$ & $6.0 \pm 0.3$ & $6.2 \pm 0.2$ & $6.6 \pm 0.1$ & $7.3 \pm 0.3^{*}$ & $7.7 \pm 0.1^{*}$ & $7.3 \pm 0.3^{*}$ \\
\hline $22: 4$ & $0.1 \pm 0.02$ & $0.06 \pm 0.02$ & $0.03 \pm 0.03$ & $0.1 \pm 0.05$ & $0.1 \pm 0.03$ & $0.1 \pm 0.03$ \\
\hline $22: 5$ & $0.4 \pm 0.1$ & $0.4 \pm 0.1$ & $0.2 \pm 0.1$ & $0.3 \pm 0.2$ & $0.5 \pm 0.1$ & $0.5 \pm 0.1$ \\
\hline \multicolumn{7}{|c|}{ n-3 series } \\
\hline $20: 5$ & $0.2 \pm 0.01$ & $0.2 \pm 0.01$ & $0.2 \pm 0.01$ & $0.2 \pm 0.01$ & $0.2 \pm 0.02$ & $0.2 \pm 0.0$ \\
\hline $22: 5$ & $0.1 \pm 0.05$ & $0.1 \pm 0.05$ & $0.2 \pm 0.00$ & $0.1 \pm 0.1$ & $0.1 \pm 0.05$ & $0.2 \pm 0.1$ \\
\hline $22: 6$ & $1.7 \pm 0.2$ & $1.7 \pm 0.2$ & $1.7 \pm 0.02$ & $1.7 \pm 0.2$ & $1.7 \pm 0.2$ & $1.7 \pm 0.2$ \\
\hline
\end{tabular}

He G2 cells, $72 \mathrm{~h}$ after passage, were incubated in fresh DME medium containing 10\% delipidated serum, $40 \mu \mathrm{M}$ LA and LOV $0.04-40 \mu \mathrm{M}$ or DMSO alone $(\leq 0.1 \%)$ for $72 \mathrm{~h}$. Cells were extracted, phospholipids separated, and fatty acid methyl esters quantitated as described in Methods. Values $(\mu \mathrm{M})$ are means \pm 1 SEM from three experiments. * Value is different from DMSO control using one-way repeated measures ANOVA with Sheffe's $F$ test for differences between means. ${ }^{\ddagger}$ Value represents the sum of $18: 1$ isomers. 
$(2.4 \pm 0.1 \%$ vs. $10.9 \pm 0.1 \%)$, indicating that $\mathrm{LDL}$ served as an efficient source of this AA precursor (Table III). LA was incorporated mainly at the expense of oleic acid, while the saturated fatty acids were not affected. Lovastatin treatment increased the relative AA content (from $6.9 \pm 0.1 \%$ to $8.3 \pm 0.3 \%$ ) and decreased LA content (from $10.9 \pm 0.1 \%$ to $8.6 \pm 0.3 \%$ ) in the LDL-loaded cells.

$L O V$ effects on the metabolism of $L A$. In order to confirm the above described LOV-induced compositional changes in the cellular phospholipid n-6 polyunsaturated fatty acids, the metabolism of $\left[{ }^{14} \mathrm{C}\right] 18: 2 n-6$ in both cell lines was followed. In the Hep G2 cell line, LOV treatment ( $10 \mu \mathrm{M}, 72 \mathrm{~h}$ ) resulted in an apparent increase in the desaturation of LA (Fig. $2 A$ ). Relative to cells treated with DMSO $(<0.1 \%)$, the percentage of ${ }^{14} \mathrm{C}$ label appearing as $18: 2 \mathrm{n}-6$ decreased, while the proportion of label in fatty acid fractions with three, four, and five double bonds increased after $18 \mathrm{~h}$ of incubation with $\left[{ }^{14} \mathrm{C}\right] \mathrm{LA}$ ( $5 \mu \mathrm{M}, 0.3 \mu \mathrm{Ci}$ ). As illustrated in Fig. 2, the maximal change in LA metabolism was seen when LOV was given to freshly passaged cells ( $72 \mathrm{~h}, 10 \mu \mathrm{M})$.

In control cells $(n=3), 87.7 \pm 0.6 \%$ of the total label was found in phospholipids while $9.3 \pm 0.9 \%, 2.2 \pm 1.2 \%$, and $0.7 \pm 0.1 \%$ were associated with the triglycerides, free fatty acids, and cholesterol esters, respectively. After LOV treatment ( $10 \mu \mathrm{M}, 72 \mathrm{~h}$ ), a marginal decrease in the percentage of label was found in the phospholipid $(81.9 \pm 1.5 \%)$, free fatty acid $(1.4 \pm 0.6 \%)$, and cholesterol ester $(0.3 \pm 0.01 \%)$ fractions, while more label was associated with the triglycerides $(16.4 \pm 1.4 \%)$.

Under the identical experimental conditions, control MM6 cells (DMSO $\leq 0.1 \%$ ) desaturated proportionally more $\left[{ }^{14} \mathrm{C}\right] 18: 2 \mathrm{n}-6$ than did the control Hep G2 cells (Fig. $2 B$ ). In

Table III. Phospholipid Fatty Acid Composition of Hep G2 Cells Incubated with LOV and LDL

\begin{tabular}{cccc}
\hline & DMSO & DMSO + LDL & LOV + LDL \\
\hline Saturated & & & \\
c16:0 & $35.2 \pm 0.9$ & $34.1 \pm 0.3$ & $35.6 \pm 0.8$ \\
c18:0 & $6.8 \pm 0.4$ & $6.7 \pm 0.3$ & $6.9 \pm 0.3$ \\
Monoene & & & \\
c18:1 & $44.9 \pm 0.6$ & $36.9 \pm 0.7^{\ddagger}$ & $35.1 \pm 0.4^{\ddagger}$ \\
Polyunsaturated & & & \\
n-6 series & & & \\
$18: 2$ & $2.4 \pm 0.1$ & $10.9 \pm 0.1^{\ddagger}$ & $8.6 \pm 0.3^{* \ddagger}$ \\
$20: 3$ & $0.8 \pm 0.03$ & $1.3 \pm 0.02$ & $1.7 \pm 0.08$ \\
$20: 4$ & $6.6 \pm 0.4$ & $6.9 \pm 0.2$ & $8.3 \pm 0.3^{* \ddagger}$ \\
$22: 4$ & $0.1 \pm 0.01$ & $0.1 \pm 0.01$ & $0.1 \pm 0.02$ \\
$22: 5$ & $0.4 \pm 0.04$ & $0.3 \pm 0.02$ & $0.4 \pm 0.04$ \\
n-3 series & & & \\
$20: 5$ & $0.4 \pm 0.04$ & $0.6 \pm 0.02$ & $0.5 \pm 0.04$ \\
$22: 5$ & $0.3 \pm 0.06$ & $0.2 \pm 0.03$ & $0.3 \pm 0.02$ \\
$22: 6$ & $2.2 \pm 0.2$ & $2.2 \pm 0.1$ & $2.6 \pm 0.1$ \\
\hline
\end{tabular}

Freshly passaged Hep G2 cells were incubated with LOV $(10 \mu \mathrm{M})$ or DMSO alone $(\leq 0.1 \%)$ for $72 \mathrm{~h}$ and with LDL $(100 \mu \mathrm{g} / \mathrm{ml})$ for the last $24 \mathrm{~h}$. Cells were extracted, phospholipids separated, and fatty acid methyl esters quantitated as described in Methods. Values are means \pm 1 SEM from three experiments. Significant effects of ${ }^{\ddagger} \mathrm{LOV}$ and ${ }^{*} \mathrm{LDL}$ incubation respectively, using one-way repeated measures ANOVA with Sheffe's $F$ test for differences between means. "Value represents the sum of $18: 1$ isomers.
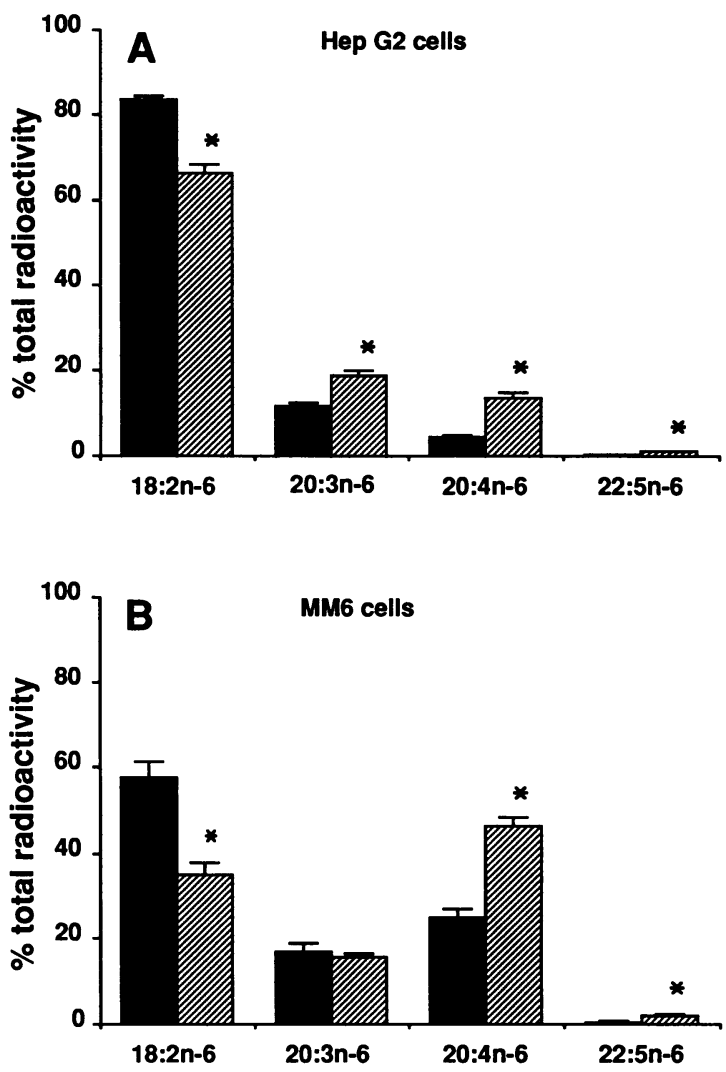

Figure 2. Effect of LOV on the desaturation of $\left[{ }^{14} \mathrm{C}\right]$ LA. Freshly passaged $(A)$ Hep $\mathrm{G} 2$ cells and $(B)$ MM6 cells were incubated with 10 $\mu \mathrm{M}$ LOV (hatched bars) or DMSO ( $\leq 0.1 \%$, solid bars) for $72 \mathrm{~h}$ and with [ $\left.{ }^{14} \mathrm{C}\right] \mathrm{LA}(0.3 \mu \mathrm{Ci}, 5 \mu \mathrm{M})$ for the last $18 \mathrm{~h}$. Total lipids were extracted and the distribution of label in fatty acid fractions containing two, three, four, or five double bonds was determined by argentation chromatography as described in Methods. The 20:3n-6 and $20: 4 n-6$ fractions also include the minor $18: 3 n-6$ and $22: 4 n-6$ fatty acids, respectively. Bars represent means \pm 1 SEM of duplicate determinations from 15 (Hep G2) and 8 (MM6) experiments. *Value is significantly different from DMSO-treated control by means of paired $t$ test, $P \leq 0.01$.

this cell line, $\operatorname{LOV}(10 \mu \mathrm{M}, 72 \mathrm{~h})$ also significantly decreased the proportion of ${ }^{14} \mathrm{C}$ label in 18:2n-6 while increasing the percentage of ${ }^{14} \mathrm{Clabel}$ appearing in fatty acids containing four and five double bonds (Fig. $2 \mathrm{~B}$ ).

In both cell lines, the cellular uptake of $\left[{ }^{14} \mathrm{C}\right] 18: 2 n-6$ after the 18 -h incubation period was $\leq 85 \%$ and was not significantly affected by LOV treatment. DMSO in the concentrations used had no effect on $\left[{ }^{14} \mathrm{C}\right]$ 18:2n-6 metabolism (data not shown ). Furthermore, the LOV effect was similar in cells given $\left[{ }^{14} \mathrm{C}\right] 18: 2 \mathrm{n}-6$ in the presence or absence of $10 \%$ FCS in medium.

Reversibility of the LOV effect on LA metabolism. In order to explore the possible mechanisms behind the LOV-induced changes in LA metabolism, their reversibility after the coincubation with MVA, cholesterol, or lipoproteins was examined in both cell lines. Our results indicate differences in the response to this treatment between the two cell lines.

In the Hep G2 cell line, the LOV effect on LA desaturation could be reversed by means of coincubation with MVA ( 500 $\mu \mathrm{M}$, Fig. 3). The maximal reversal was obtained in LOVtreated cells coincubated with MVA for the entire 72-h period. 
Ethanol alone $(\mathbf{0 . 1 \%})$ had no such effect. Furthermore, MVA alone $(500 \mu \mathrm{M})$ produced no changes in the metabolism of LA in control cells (data not shown). The simultaneous coincubation of LOV-treated cells ( $10 \mu \mathrm{M}, 72 \mathrm{~h}$ ) with either free cholesterol $(15 \mu \mathrm{g} / \mathrm{ml}$, dissolved in ethanol, final concentration $0.1 \%)$, LDL, or acetyl LDL ( $100 \mu \mathrm{g} / \mathrm{ml}$ protein) did not reverse the LOV effect on LA metabolism (Table IV $A$ ).

In contrast to the Hep G2 cells, coincubation of LOVtreated MM6 cells with neither MVA in concentrations up to 1 $\mathrm{mM}$, nor with cholesterol, LDL, or acetyl LDL could signifcantly reverse the LOV effect (Table $\mathrm{V} A$ ).

The potential for other inhibitors of $H M G C o A$ reductase to stimulate the desaturation of LA was investigated in control cells incubated with cholesterol, LDL, or acetyl LDL. In both the Hep G2 and MM6 cell lines, none of these sources of cholesterol influenced the metabolism of linoleic acid (Tables IV $B$ and $\mathrm{V} B$, respectively). This lack of effect may reflect the fundamental difference between the sterol-mediated transcriptional and the LOV-mediated post-transcriptional regulation of HMGCoA reductase activity $(3,4)$.

Fatty acid composition of lipids secreted by Hep $G 2$ cells. In order to investigate whether the LOV-mediated increase in hepatocyte LA desaturation was reflected in in situ synthesized lipoproteins, we examined the fatty acid composition of total phospholipids, triglycerides, and cholesterol esters secreted into culture medium by the Hep G 2 cells. As shown in Table VI, LOV increased the relative content of AA in all three fractions in a dose-dependent manner. This effect was best seen in the phospholipids, the most abundant lipid secreted by this cell line $(24,25)$, where statistically significant changes occurred with as little as $0.4 \mu \mathrm{M}$ LOV. In the phospholipid fraction, a significant increase in the minor $22: 4 n-6$ and the PUFA n-3 fatty acids was also observed. Furthermore, LOV reduced palmitic acid content in the secreted phospholipid and triglyceride

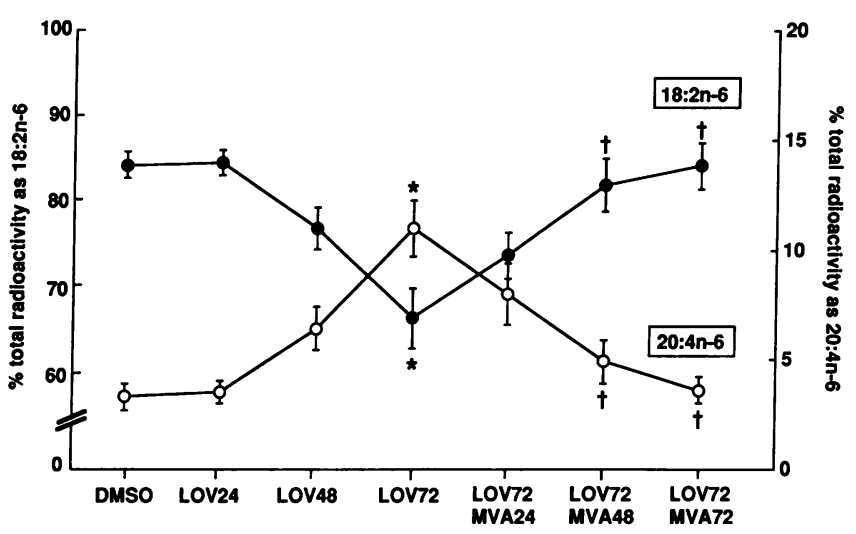

Figure 3. Metabolism of LA in Hep G2 cells incubated with LOV and MVA for different time periods. Freshly passaged Hep G2 cells were incubated with $10 \mu \mathrm{M}$ lovastatin for the last 24,48 , or $72 \mathrm{~h}$, or with $10 \mu \mathrm{M} \mathrm{LOV}$ for $72 \mathrm{~h}$ and $500 \mu \mathrm{M}$ MVA for the last 24,48 , or $72 \mathrm{~h}$ and $\left[{ }^{14} \mathrm{C}\right] 18: \mathrm{n}-6(0.3 \mu \mathrm{Ci}, 5 \mu \mathrm{M})$ for the last $18 \mathrm{~h}$. Total lipids were extracted and the distribution of label in fatty acids with two to five double bonds were determined by argentation chromatography as described in Methods. Values are means \pm 1 SEM of the percentage of total radioactivity recovered as $18: 2 n-6$ and the sum of $20: 4 n-6$ and the minor 22:4n-6 in duplicate measurements from four experiments. Values are significantly different from the ${ }^{*} \mathrm{DMSO}$-control and ${ }^{\dagger} \mathrm{LOV}$ 72-h-treated cells, respectively, using one-factor ANOVA with Sheffe $F$ test for differences between means, $P \leq 0.05 \%$.
Table IV. Metabolism of LA in DMSO or LOV-treated Hep G2 Cells Coincubated with Various Sources of Cholesterol

\begin{tabular}{lccc}
\hline & $18: 2 \mathrm{n}-6$ & $20: 3 \mathrm{n}-6$ & $20: 4 \mathrm{n}-6$ \\
\hline & & \% total radioactivity \\
A. & & \\
LOV only & $65.1 \pm 3.5$ & $18.3 \pm 1.6$ & $15.4 \pm 1.9$ \\
LOV + CHOL & $68.5 \pm 3.0$ & $17.5 \pm 1.6$ & $13.0 \pm 1.5$ \\
LOV + LDL & $70.9 \pm 1.5$ & $15.8 \pm 1.2$ & $12.3 \pm 1.7$ \\
LOV + aLDL & $64.8 \pm 5.4$ & $15.9 \pm 3.0$ & $17.9 \pm 2.3$ \\
B. & & & \\
DMSO only & $84.4 \pm 1.7$ & $11.0 \pm 1.1$ & $4.2 \pm 0.6$ \\
DMSO + CHOL & $84.9 \pm 1.9$ & $10.9 \pm 1.1$ & $4.0 \pm 0.8$ \\
DMSO + LDL & $89.7 \pm 0.5$ & $7.2 \pm 0.3$ & $2.8 \pm 0.3$ \\
DMSO + aLDL & $87.6 \pm 2.3$ & $7.8 \pm 1.6$ & $4.1 \pm 1.0$ \\
& & & \\
\end{tabular}

Freshly passaged Hep G2 cells were incubated with (A) $10 \mu \mathrm{M}$ LOV or (B) $0.1 \%$ DMSO and with either cholesterol (CHOL; $15 \mu \mathrm{g} / \mathrm{mL}$ ), LDL ( $100 \mu \mathrm{g}$ protein $/ \mathrm{ml})$, or acetyl LDL (aLDL, $100 \mu \mathrm{g}$ protein $/ \mathrm{ml}$ ) for $72 \mathrm{~h}$ and with $\left[{ }^{14} \mathrm{C}\right] 18: 2 \mathrm{n}-6(0.3 \mu \mathrm{Ci}, 5 \mu \mathrm{M})$ for the last $18 \mathrm{~h}$. Total lipids were extracted and the distribution of label in fatty acids with two to five double bonds were determined by argentation chromatography as described in Methods. 20:3n-6 and 20:4n-6 fractions also include the minor $18: 3 n-6$ and 22:4n-6 fatty acids, respectively. Values are means \pm 1 SEM from duplicate measurements from three to eight experiments.

and increased stearic acid in the phospholipid and cholesterol ester fractions. Unlike for cellular phospholipids, however, LOV did not decrease the LA content of the secreted lipids.

Table V. Metabolism of LA in DMSO or LOV-treated Mono Mac 6 Cells Coincubated with MVA and Various Sources of Cholesterol

\begin{tabular}{ccc}
\hline $18: 2 n-6$ & $20: 3 n-6$ & $20: 4 n-6$ \\
\hline \multicolumn{3}{c}{ \% total radioactivity }
\end{tabular}

A.

$\begin{array}{llll}\text { LOV only } & 37.1 \pm 2.3 & 13.8 \pm 0.6 & 46.3 \pm 2.5 \\ \text { LOV + MVA } & 44.4 \pm 5.5 & 13.9 \pm 0.4 & 40.4 \pm 5.1 \\ \text { LOV + CHOL } & 35.1 \pm 4.4 & 14.4 \pm 1.8 & 48.0 \pm 4.6 \\ \text { LOV + LDL } & 39.8 \pm 3.3 & 12.1 \pm 0.8 & 45.6 \pm 2.8 \\ \text { LOV + aLDL } & 34.6 \pm 2.1 & 13.4 \pm 0.8 & 48.7 \pm 1.6\end{array}$

B.

$\begin{array}{llll}\text { DMSO only } & 63.1 \pm 3.9 & 15.6 \pm 0.8 & 20.8 \pm 1.6 \\ \text { DMSO + MVA } & 52.9 \pm 8.3 & 16.6 \pm 1.4 & 29.7 \pm 9.4 \\ \text { DMSO + CHOL } & 62.1 \pm 2.8 & 19.3 \pm 1.8 & 17.9 \pm 2.7 \\ \text { DMSO + LDL } & 65.1 \pm 1.9 & 17.7 \pm 1.0 & 16.5 \pm 2.8 \\ \text { DMSO + aLDL } & 59.6 \pm 3.9 & 16.5 \pm 0.8 & 23.3 \pm 4.5\end{array}$

Freshly passaged MM6 cells were incubated with (A) $10 \mu \mathrm{M}$ LOV or (B) $0.1 \%$ DMSO and with either MVA ( $1 \mathrm{mM})$, cholesterol (CHOL; $15 \mu \mathrm{g} / \mathrm{ml}$ ), LDL (100 $\mu \mathrm{g}$ protein/ml), or acetyl LDL (aLDL; $100 \mu \mathrm{g}$ protein) for $72 \mathrm{~h}$ and with $\left[{ }^{14} \mathrm{C}\right] 18: 2 \mathrm{n}-6(0.3 \mu \mathrm{Ci}, 5 \mu \mathrm{M})$ for the last $18 \mathrm{~h}$. Total lipids were extracted and the distribution of label in fatty acids with two to five double bonds were determined by argentation chromatography as described in Methods. The 20:3n-6 and 20:4n-6 fractions also include the minor $18: 3 n-6$ and $22: 4 n-6$ fatty acids, respectively. Values are means \pm 1 SEM from duplicate measurements from three or four experiments. 


\begin{tabular}{|c|c|c|c|c|c|}
\hline & \multirow[b]{2}{*}{ DMSO } & \multicolumn{4}{|c|}{$\operatorname{LOV}(\mu \mathrm{M})$} \\
\hline & & 0.04 & 0.4 & 4 & 10 \\
\hline \multicolumn{6}{|l|}{ Phospholipids } \\
\hline c16:0 & $49.0 \pm 0.4$ & $48.1 \pm 0.4$ & $43.8 \pm 0.5^{*}$ & $41.9 \pm 0.6^{*}$ & $42.2 \pm 0.6^{*}$ \\
\hline $\mathrm{c} 18: 0$ & $4.7 \pm 0.3$ & $4.3 \pm 0.3$ & $5.5 \pm 0.4$ & $5.8 \pm 0.4^{*}$ & $6.1 \pm 0.2^{*}$ \\
\hline $\mathrm{c} 18: 1^{\ddagger}$ & $38.1 \pm 0.6$ & $39.2 \pm 0.4$ & $39.5 \pm 0.8$ & $41.1 \pm 1.1$ & $40.0 \pm 0.9$ \\
\hline c18:2n-6 & $3.7 \pm 0.2$ & $3.8 \pm 0.2$ & $4.1 \pm 0.4$ & $3.2 \pm 0.4$ & $3.0 \pm 0.5$ \\
\hline c20:4n-6 & $2.9 \pm 0.2$ & $3.5 \pm 0.3$ & $4.3 \pm 0.2^{*}$ & $4.7 \pm 0.2^{*}$ & $4.7 \pm 0.3^{*}$ \\
\hline$c 22: 5 n-6$ & $0.15 \pm 0.03$ & $0.24 \pm 0.01$ & $0.27 \pm 0.02$ & $0.34 \pm 0.01^{*}$ & $0.41 \pm 0.1^{*}$ \\
\hline$\Sigma c 20: 5,22: 5,22: 6 n-3$ & $0.86 \pm 0.08$ & $0.83 \pm 0.05$ & $1.46 \pm 0.10^{*}$ & $1.58 \pm 0.21^{*}$ & $1.82 \pm 0.32 *$ \\
\hline \multicolumn{6}{|l|}{ Triglycerides } \\
\hline c16:0 & $32.1 \pm 0.8$ & $29.7 \pm 0.3$ & $28.6 \pm 0.5^{*}$ & $25.9 \pm 0.7^{*}$ & $25.2 \pm 0.3^{*}$ \\
\hline $\mathrm{cl} 18: 0$ & $3.1 \pm 0.2$ & $2.7 \pm 0.1$ & $3.1 \pm 0.3$ & $3.5 \pm 0.2$ & $3.6 \pm 0.2$ \\
\hline $\operatorname{c18:1^{\ddagger }}$ & $62.3 \pm 1.1$ & $65.5 \pm 0.1$ & $64.7 \pm 1.4$ & $66.3 \pm 1.8$ & $66.3 \pm 1.1$ \\
\hline c18:2n-6 & $1.5 \pm 0.1$ & $1.6 \pm 0.02$ & $1.8 \pm 0.3$ & $1.8 \pm 0.2$ & $1.9 \pm 0.4$ \\
\hline c20:4n-6 & $0.36 \pm 0.06$ & $0.33 \pm 0.03$ & $0.38 \pm 0.04$ & $0.61 \pm 0.04^{*}$ & $0.69 \pm 0.08^{*}$ \\
\hline \multicolumn{6}{|l|}{ Cholesterol ester } \\
\hline c16:0 & $29.7 \pm 0.6$ & $29.5 \pm 0.5$ & $29.0 \pm 0.6$ & $26.8 \pm 1.1$ & $28.6 \pm 1.5$ \\
\hline c18:0 & $4.9 \pm 0.3$ & $4.1 \pm 0.1$ & $5.1 \pm 0.4$ & $8.4 \pm 0.8^{*}$ & $9.9 \pm 0.6^{*}$ \\
\hline c18:1 $1^{\ddagger}$ & $58.5 \pm 1.6$ & $58.0 \pm 1.1$ & $56.6 \pm 1.7$ & $54.3 \pm 1.6$ & $52.6 \pm 2.8$ \\
\hline c18:2n-6 & $4.3 \pm 0.5$ & $6.9 \pm 1.6$ & $5.9 \pm 1.1$ & $4.4 \pm 1.3$ & $4.7 \pm 1.5$ \\
\hline c20:4n-6 & $1.4 \pm 0.2$ & $1.3 \pm 0.03$ & $2.1 \pm 0.3$ & $3.9 \pm 1.4^{*}$ & $3.2 \pm 0.6^{*}$ \\
\hline
\end{tabular}

Freshly passaged Hep G2 cells were incubated with LOV $0-10 \mu \mathrm{M}$ or DMSO alone $(\leq 0.1 \%)$ on days 1 through 8 , with $10 \mu \mathrm{M}$ LA on days 4-6 and in serum-free DME on days 7 and 8 . Total lipids secreted into the medium were isolated, lipid classes separated, and fatty acid methyl esters quantitated as described in Methods. Values $(\mu \mathrm{M})$ are means \pm 1 SEM from three to seven experiments. ${ }^{*}$ Value is different from DMSO control using one-way repeated measures ANOVA with Sheffe's $F$ test for differences between means. ${ }^{\ddagger}$ Value represents the sum of $18: 1$ isomers.

Thromboxane synthesis in the MM6 cell line. To investigate the potential functional consequences of a LOV-mediated rise in cellular AA levels, its effect on thromboxane synthesis

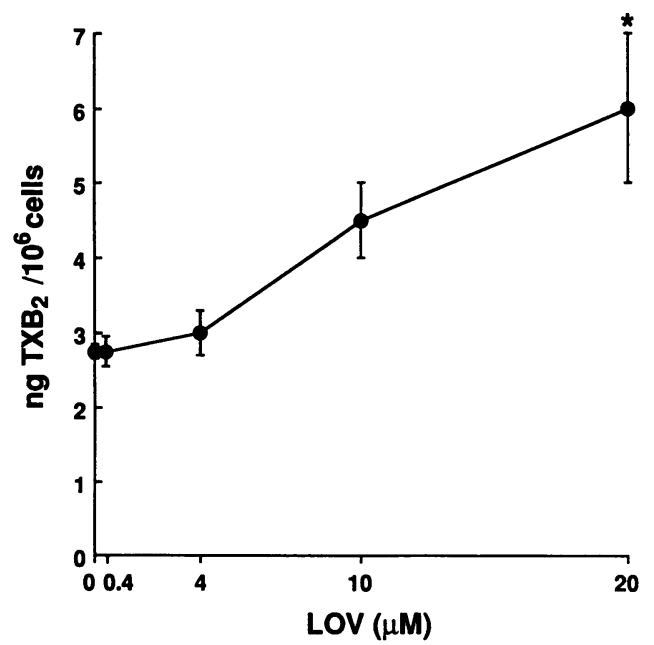

Figure 4. Effect of LOV on thromboxane release by MM6 cells. Freshly passaged MM6 cells were incubated with DMSO $(\leq 0.1 \%)$ or 0.4-20 $\mu \mathrm{M}$ lovastatin for $72 \mathrm{~h}$, and LA $(10 \mu \mathrm{M})$ for the last $24 \mathrm{~h}$. Cells were resuspended in buffer and stimulated with $1 \mu \mathrm{M}$ calcium ionophore A23187 for $5 \mathrm{~min}$, and the thromboxane released was determined as described in Methods. Bars represent means \pm 1 SEM of duplicate measurements from five experiments. *Value is significantly different from the DMSO-treated control using one-factor ANOVA with Sheffe $F$ test for differences between means, $P \leq 0.05$. was examined in the MM6 cell line. LOV increased the thromboxane synthesis in A23187-stimulated cells in a dose-dependent manner (Fig. 4). Thromboxane release was also marginally higher after treatment with $20 \mu \mathrm{M} \mathrm{LOV}$ in unstimulated cells ( 5 min, DMSO $0.1 \%$, data not shown). This effect could be reversed by means of coincubation with $500 \mu \mathrm{M}$ MVA (Fig. 5 ), while mevalonic acid added to control cells had no influence on thromboxane synthesis (data not shown). In contrast, cells incubated with LOV $(10 \mu \mathrm{M}, 72 \mathrm{~h})$ and $\operatorname{LDL}(100 \mu \mathrm{g} / \mathrm{ml})$ released more thromboxane than cells treated with $\mathrm{LOV}$ alone (Fig. 5). Preliminary results indicate that LDL or acetyl LDL alone also stimulate thromboxane release in control cells (data not shown).

Influence of LOV on cellular lipids. In the Hep G2 cells, 10 and $40 \mu \mathrm{M} \mathrm{LOV}(72 \mathrm{~h})$ induced a dose-dependent accumulation of cellular triglycerides, while cellular phospholipids were marginally elevated at $40 \mu \mathrm{M} \mathrm{LOV}, P<0.10$ (Table VII). In contrast, the cellular cholesterol content of both Hep G2 ( Table VII) and MM6 (data not shown) cells was not affected.

Influence of LOV on cell proliferation and viability. In the MM6 cell line, LOV produced a dose-dependent suppression of cellular proliferation which was statistically significant at the $20 \mu \mathrm{M}$ dose level (Fig. 6). Cell proliferation was partially recovered by means of coincubation with MVA $(500 \mu \mathrm{M})$, while cell proliferation after LDL $(100 \mu \mathrm{g} / \mathrm{ml})$ was further reduced. The cell viability, as judged by ethidium bromide/acridin orange fluorescence, was $91 \%$ in control cells and 86 and $76 \%$ in cells treated with 10 and $20 \mu \mathrm{M} \mathrm{LOV}$, respectively. Cells coincubated with $20 \mu \mathrm{M} \mathrm{LOV}$ and MVA were $89 \%$ viable, while the viability of cells coincubated with LOV and LDL was further 


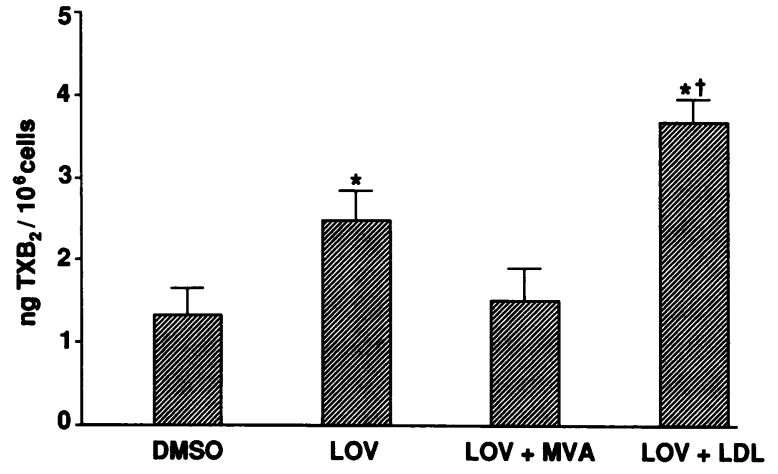

Figure 5. Effect of MVA and LDL on thromboxane release by LOVtreated MM6 cells. Freshly passaged MM6 cells were incubated with DMSO $(\leq 0.1 \%)$, LOV alone $(10 \mu \mathrm{M})$ or with LOV $(10 \mu \mathrm{M})$ and MVA $(500 \mu \mathrm{M})$ or LDL $(100 \mu \mathrm{g} / \mathrm{ml})$ for $72 \mathrm{~h}$ and with $10 \mu \mathrm{M} \mathrm{LA}$ for the last $24 \mathrm{~h}$. Cells were resuspended in buffer and stimulated with calcium ionophore $\mathrm{A} 23187(1 \mu \mathrm{M})$ for $5 \mathrm{~min}$. Thromboxane release was determined as described in Methods. Values are means \pm SEM of duplicate measurements from three or four experiments. Values are different from ${ }^{*}$ DMSO-treated and ${ }^{\dagger} \mathrm{LOV}$-treated cells respectively, by Fisher PLSD test.

reduced. Lipoproteins added to control cells (DMSO $<0.1 \%$ ) had no effect on cell viability.

In the Hep G2 cell line, a LOV concentration up to $10 \mu \mathrm{M}$ did not influence cell proliferation, as determined by means of cellular protein measurement, while $40 \mu \mathrm{M}$ LOV reduced proliferation by $20 \%$ (data not shown). The cell viability was $>90 \%$ at $0-40 \mu \mathrm{M}$ LOV.

\section{Discussion}

Most clinical studies of HMGCoA reductase inhibitors focus on drug-mediated changes on total lipid or lipoprotein profiles as underlying mechanisms for their therapeutic effects. Less attention has been given to effects of these agents on fatty acid metabolism. However, Doormaals et al. (5) have found decreased levels of LA and increased levels of AA in erythrocytes of patients receiving simvastatin therapy. Similarly, a decrease in LA content of LDL triglyceride and cholesterol ester (7), as well as an increase in total PUFA content of VLDL, LDL, and

Table VII. Effect of LOV on Cellular Triglyceride, Phospholipid, and Cholesterol Content of Hep G2 Cells

\begin{tabular}{lccc}
\hline & Triglyceride & Phospholipid & Cholesterol \\
\hline & $\mu g / m g$ protein & $\mu m o l / m g$ protein & $\mu g / m g$ protein \\
& & & \\
DMSO $(0.1 \%)$ & $106.0 \pm 14.8$ & $0.49 \pm 0.02$ & $26.45 \pm 1.02$ \\
LOV $(10 \mu \mathrm{M})$ & $170.6 \pm 8.6^{*}$ & $0.47 \pm 0.01$ & $24.52 \pm 1.89$ \\
LOV $(40 \mu \mathrm{M})$ & $239.1 \pm 13.9^{* \neq}$ & $0.61 \pm 0.06$ & $27.84 \pm 2.71$
\end{tabular}

Freshly passaged Hep G2 cells, grown in DME medium containing $10 \%$ FCS, were incubated with DMSO $(0.1 \%)$, or LOV (10 or 40 $\mu \mathrm{M}$ ) for $72 \mathrm{~h}$. Subsequently, cells were washed and extracted, and total cellular triglyceride, phospholipid, and cholesterol were measured as described in Methods. Values are means \pm SEM of triplicate measurements from four experiments. Value is different from * DMSO control and ${ }^{\ddagger}$ from LOV $10 \mu \mathrm{M}$ using one-way repeated measures ANOVA with Sheffe's $F$ test for differences between means.

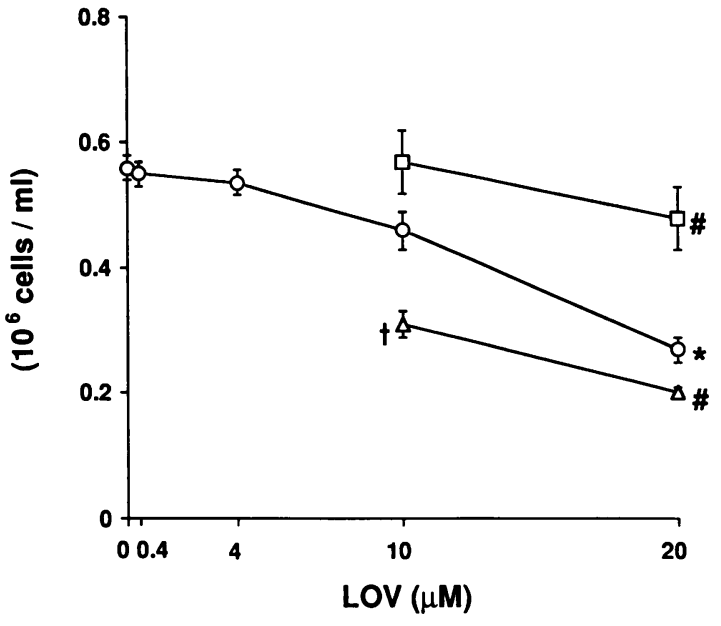

Figure 6. Freshly passaged MM6 cells were seeded at $0.2 \times 10^{6}$ cells/ $\mathrm{ml}$ and incubated with DMSO $(0.1 \%), \operatorname{LOV}(0.4-20 \mu \mathrm{M}, \circ)$ or 20 $\mu \mathrm{M}$ LOV with MVA ( $1 \mathrm{mM}, \square)$ or LDL $(100 \mu \mathrm{g}$ protein $/ \mathrm{ml}, \Delta)$ for $72 \mathrm{~h}$ and with $10 \mu \mathrm{M}$ LA for the last $24 \mathrm{~h}$. Cells were counted in the original medium. Symbols are means \pm 1 SEM from three to eight experiments. *Value is significantly different from DMSO-treated control using one-factor ANOVA with Sheffe $F$ test for differences between means, $P \leq 0.05$. Values are different from ${ }^{\dagger} \mathrm{LOV} 10 \mu \mathrm{M}$ and ${ }^{*}$ LOV $20 \mu$ M-treated cells, respectively, by Student's $t$ test.

HDL triglyceride (6) in patients undergoing HMGCoA reductase inhibitor therapy has been reported. The present study was undertaken to examine the effects of LOV on the metabolism of LA in the human hepatoma (Hep G2) and monocytic MM6 cell lines. We demonstrate that LOV increases the desaturation of LA and thus the cellular phospholipid content of AA. The higher availability of cellular AA in turn results in higher AA content of lipids secreted by the Hep G2 cells and increased release of thromboxane in the MM6 cells.

HMGCoA reductase inhibitors may influence fatty acid desaturase activity secondary to their specific inhibition of the cholesterol biosynthetic pathway or through their nonspecific action on systems related to drug metabolism. With respect to the first possibility, manipulation of membrane cholesterol content is known to have profound effects on membrane fluidity and function of membrane-associated enzymes $(1,2)$. Increased microsomal membrane fluidity, AA content and enhanced $\Delta 5$ and 6 desaturase activities have been documented in liver microsomes of rats fed a sterol-free diet (9). The feeding of cholesterol-rich diets, on the other hand, can lead to decreased liver microsomal $\Delta 5$ and 6 desaturase activity and AA content $(8,10,26)$. Although our findings of increased desaturation of LA in LOV-treated cells tend to parallel the above results, the effect observed does not appear to be closely related to cellular cholesterol content. As previously described in other cell culture systems (27), we find no significant reductions in cellular cholesterol levels after LOV treatment. We assume that the reduction of de novo cholesterol synthesis, produced by LOV, is sufficiently compensated for by increased uptake of cholesterol from the cell culture media, both of which contained 10\% FCS. In support of this, both the Hep G2 (14) and MM6 (our own observation) cell lines have functional LDL receptors. Furthermore, coincubation of LOV-treated cells with free cholesterol as well as with lipoproteins did not reverse the LOV-induced changes in LA metabolism. 
Alternatively, it is becoming increasingly clear that early as well as later intermediates of the cholesterol biosynthetic pathway are vital for diverse cellular functions $(3,4)$. The inhibition of the synthesis of early metabolites of cholesterogenesis such as farnesyl or geranyl pyrophosphates, leading to decreased prenylation of a variety of proteins, affect cell growth $(28,29)$, chemotaxis $(27)$, and signal transduction $(28,30)$. With respect to the later metabolites of cholesterogenesis, dolichol phosphates are required for glycoprotein synthesis, while ubiquinone and heme are involved in the electron transport chain (4).

In our experiments, the LOV-mediated changes in LA metabolism in the Hep G2 cell line were completely reversed by the addition of MVA. In the MM6 cell line, the LOV-induced increase in thromboxane release was reduced with MVA, although under the experimental conditions used, the conversion of LA to AA was not. Coincubation of LOV-treated cells with LDL, on the other hand, enhanced thromboxane release. Similar effects of LDL on thromboxane release has been seen in endothelium (31) and platelets (32). Taken together, our data strongly suggest that a decrease in the availability of one or more of the early intermediates of cholesterogenesis were responsible for the observed cellular effects of LOV on the microsomal desaturation of PUFA and the subsequent synthesis of eicosanoids.

Treatment with LOV and related compounds results in a marked accumulation of the microsomal inactive HMGCoA reductase enzyme and proliferation of the endoplasmic reticulum (33). Peroxisomal hyperplasia with concomitant increases in fatty acid synthesis and triglyceride and phospholipid accumulation in cultured human keratinocytes after LOV has also been recently reported (34). We also observe accumulation of cellular triglyceride and increased uptake of fatty acid into the triglyceride lipid fraction in our LOV-treated Hep G2 cells. Thus, LOV may act similarly to other lipid-lowering drugs such as the fibrates, for which peroxisomal hyperplasia and induction of endoplasmic reticulum enzymes $(35,36)$, as well as perturbations in fatty acid metabolism (37-39) have been reported. Induction of fatty acid desaturation in proliferating hepatic endoplasmic reticulum in response to treatment with polychlorinated biphenyls suggests that fatty acid desaturases are cytochrome P450-dependent monooxygenases (40). Cytochrome $\mathrm{P} 450$ enzymes are also responsible for the oxidative metabolism of lovastatin (41). Thus HMGCoA reductase inhibitors may stimulate LA desaturation through the induction of the endoplasmic reticulum. Recently, however, no nonspecific activation of several cytochrome P450-linked enzymes has been detected in rats treated with simvastatin, despite elevations in microsomal AA acid content (42). As in the present study, some of the above cited inhibitor-induced effects in human keratinocytes were reversible with MVA as well as with lipoproteins (34). Thus even in this case, LOV would appear to act specifically via its suppression of the cholesterol synthesis pathway.

The hepatoma Hep G2 cell line, used extensively in studies of liver lipid metabolism (14), is an appropriate cell model in the study of effects of HMGCoA reductase inhibitors in the liver, the target organ of these drugs. We show increases in arachidonic acid content in lipids secreted by the Hep G2 cells at lovastatin doses equivalent to plasma LOV concentrations of patients undergoing LOV therapy (43). Even higher transient concentrations may be present in the liver, where LOV is cleared in the first passage. Our findings in this cell line support in vivo studies $(5,42)$ that indicate that the use of HMGCoA inhibitors leads to an increased availability of AA in hepatic and extrahepatic tissues. Our findings in Hep G2 cells coincubated with LDL also suggest that the LOV-mediated increase in hepatic lipoprotein clearance, and thus increased delivery of LA-rich cholesterol ester to the liver cell, may contribute to this effect.

Our findings in the MM6 cell line, considered to be a good model for the peripheral blood monocyte (15), further suggest potential functional consequences of LOV in the periphery, namely the increased synthesis of thromboxane. This may be the consequence of a direct LOV action in the periphery or an increased supply of AA via lipoproteins secreted by the liver, to eicosanoid-producing tissues.

In summary, the present in vitro finding of increased conversion of LA to AA by the Hep G2 and MM6 cells, and the concomitant increase in AA content of lipids secreted by the Hep $\mathrm{G} 2$ cells support clinical findings of increased systemic AA levels in patients undergoing $\mathrm{HMGCoA}$ reductase inhibitor therapy. At the cellular level, this effect appears to be strongly linked to a decrease in the availability of early nonsterol intermediates of the cholesterol synthesis pathway, and thus possibly to the decreased prenylation of cellular proteins. This may have impact on the composition of cellular fatty acids and on the systemic synthesis of eicosanoids. The elucidation of the mechanisms involved, and their physiological significance are worthy of further study.

\section{Acknowledgments}

We thank Mr. R. Scheithe for the preparation of lipoproteins and assays for the LDL and scavenger receptors in our cell lines.

This study was supported by Bundesministerium für Forschung und Technologie, Project No. 07ERG03/7, Bonn and August-LenzStiftung, München, FRG. Dr. Hrboticky was partially supported by Alexander von Humboldt Stiftung, Bonn, FRG.

\section{References}

1. Brenner, R. R. 1990. Role of cholesterol in the microsomal membrane. Lipids. 25:581-585.

2. Yeagle, P. L. 1991. Modulation of membrane function by cholesterol. Biochemie. 73:1303-1310.

3. Goldstein, J. L., and M. S. Brown. 1990. Regulation of the mevalonate pathway. Nature (Lond.). 343:425-430.

4. Russell, D. W. 1992. Cholesterol biosynthesis and metabolism. Cardiovasc. Drugs Ther. 6:103-110.

5. Doormaal van J. J., W. J. W. Bos, F. A. J. Muskiet, and H. Doorenbos. 1989. Simvastatin influences linoleic acid metabolism. Pharm. Weekbl. 11:134135.

6. Agheli, N., and B. Jacotot. 1991. Effect of simvastatin and fenofibrate on the fatty acid composition of hypercholesterolaemic patients. Br. J. Clin. Pharmacol. 32:423-428.

7. Hong, C. Y., S. J. Lin, B. N. Chang, P. M. Shen, and M. S. Shiao. 1993. Effect of Pravastatin on fatty acid profile of low density lipoprotein in patients with hypercholesterolemia. Prostaglandins Leukotrienes Essent. Fatty Acids. 48:155-158.

8. Muriana, F. J. G., V. Ruiz-Gutierrez, and C. M. Vazquez. 1992. Influence of dietary cholesterol on polyunsaturated fatty acid composition, fluidity and membrane-bound enzymes in liver microsomes of rats fed olive and fish oil. Biochimie. 74:551-556.

9. Leikin, A. I., and R. R. Brenner. 1988. In vivo cholesterol removal from liver microsomes induces changes in fatty acid desaturase activities. Biochim. Biophys. Acta. 963:311-319.

10. Lee, J. H., I. Ikeda, and M. Sugano. 1991. Dietary cholesterol influences on various lipid indices and eicosanoid production in rats fed dietary fat desirable for the protection of ischemic heart disease. J. Nutr. Sci. Vitaminol. 37:389-399. 
11. Ntambi, J. L., S. A. Buhrow, K. H. Kaestner, R. J. Christy, E. Sibley, T. J. Kelly, and M. D. Lane. 1988. Differentiation-induced gene expression in 3T3 preadipocytes. J. Biol. Chem. 263:17291-17300.

12. Cabot, M. C., and C. J. Welsh. 1981. Fatty acid metabolism in phorbol ester-differentiating human leukemia cells. Cancer Res. 41:4910-4915.

13. Anel, A., J. Naval, B. Gonzalez, J. Uriel, and A. Pineiro. 1990. Fatty acid metabolism in human lymphocytes. II. Activation of fatty acid desaturase-elongase systems during blastic transformation. Biochim. Biophys. Acta. 1044:332339.

14. Javitt, N. B. 1990. Hep G2 cells as a resource for metabolic studies: lipoprotein, cholesterol, and bile acids. FASEB J. 4:161-168.

15. Ziegler-Heitbrock, H. W. L., E. Thiel, A. Fütterer, V. Herzog, A. Wirtz, and G. Riethmüller. 1988. Establishment of a human cell line (Mono Mac 6) with characteristics of mature monocytes. Int. J. Cancer. 41:456-461.

16. Basu, S. K., J. L. Goldstein, R. G. W. Anderson, and M. S. Brown. 1976. Degradation of cationized low density lipoprotein and regulation of cholesterol metabolism in homozygous familial hypercholesterolemia fibroblasts. Proc. Natl. Acad. Sci. USA. 73:3178-3182.

17. Markwell, M. A. K., S. M. Haas, L. L. Bieber, and N. E. Tolbert. 1987. A modification of the Lowry procedure to simplify protein determination in membrane and lipoprotein samples. Anal. Biochem. 87:206-210.

18. Kaluzny, M. A., L. A. Duncan, M. V. Merritt, and D. E. Epps. 1985. Rapid separation of lipid classes in high yield and purity using bonded phase columns. J. Lipid Res. 26:135-144.

19. Schick, P. K., and C. Levey. 1990. Reversed phase and argentation HPTLC for the separation of fatty acids and fatty aldehydes. J. Planar Chromatogr. 3:269-271.

20. Lorenz, R. L., W. M. Uedelhoven, A. Ruetzel, and P. C. Weber. 1989. A critical evaluation of urinary immunoreactive thromboxane: feasibility of its determination as a potential vascular risk indicator. Biochim. Biophys. Acta. 993:259-265.

21. Gamble, W., M. Vaughan, H. S. Kruth, and J. Avigan. 1978. Procedure for determination of free and total cholesterol in micro- or nanogram amounts suitable for studies with cultured cells. J. Lipid Res. 19:1068-1070.

22. Chen, P. S., T. Y. Toriba, and H. Warner. 1956. Microdetermination of phosphorus. Anal. Chem. 28:1756-1758.

23. Rodriguez-Vico, F., M. Martinez-Cayuela, E. Garcia-Peregrin, and H. Ramirez. 1989. A procedure for eliminating interferences in the Lowry method of protein determination. Anal. Biochem. 183:275-278.

24. Thrift, R. N., T. M. Forte, B. E. Cahoon, and V. G. Shore. 1986. Characterization of lipoproteins produced by the human liver cell line, Hep G2, under defined conditions. J. Lipid Res. 27:236-250.

25. Forte, T. M., M. R. McCall, B. B. Knowles, and V. G. Shore. 1989. Isolation and characterization of lipoproteins produced by human hepatomaderived cell lines other than Hep G2. J. Lipid Res. 30:817-829.

26. Leikin, A. I., and R. R. Brenner. 1987. Cholesterol-induced microsomal changes modulate desaturase activities. Biochim. Biophys. Acta. 922:294-303.

27. Kreuzer, J., J. Bader, L. Jahn, M. Hautmann, W. Kübler, and E. von Hodenberg. 1991. Chemotaxis of the monocyte cell line U937: dependence on cholesterol and early mevalonate pathway products. Atherosclerosis. 90:203-209.
28. Vincent, T. S., E. Wülfert, and E. Merler. 1991. Inhibition of growth factor signaling pathways by lovastatin. Biochem. Biophys. Res. Commun. 180:12841289.

29. Jakobisiak, M., S. Bruno, J. S. Skierski, and Z. Darzynkiewicz. 1991. Cell cycle-specific effects of lovastatin. Proc. Natl. Acad. Sci. USA. 88:3628-3632.

30. Deanin, G. G., J. L. Cutts, J. R. Pfeiffer, and J. M. Oliver. 1991. The role of isoprenoid metabolism in IgE receptor-mediated signal transduction. J. Im munol. 146:3528-3535.

31. Beitz, J., P. Hoffmann, C. Taube, A. Beitz, and W. Förster. 1985. Low density lipoproteins of male donors decrease prostacyclin and enhance thromboxane release from rat aortas perfused under pulsatile pressure. Biomed. Biochim. Acta. 44:1681-1686.

32. Beitz, J., M. Panse, and W. Förster. 1985. Low density lipoproteins from male volunteers stimulated the thromboxane formation by human platelets. Pros taglandins Leukotrienes Med. 10:443-448.

33. Singer, I. I., S. Scott, D. M. Kazazis, and J. W. Huff. 1988. Lovastatin, an inhibitor of cholesterol synthesis, induces hydroxymethylglutaryl-coenzyme A reductase directly on membranes of expanded smooth endoplasmic reticulum in rat hepatocytes. Proc. Natl. Acad. Sci. USA. 85:5264-5268.

34. Williams, M. L., G. K. Menon, and K. P. Hanley. 1992. HMG-CoA reductase inhibitors perturb fatty acid metabolism and induce peroxisomes in keratinocytes. J. Lipid Res. 33:193-208.

35. Lock, E. A., A. M. Mitchell, and C. R. Elcombe. 1989. Biochemical mechanisms of induction of hepatic peroxisome proliferation. Annu. Rev. Pharmacol. Toxicol. 29:145-163.

36. Gibson, G. G., T. C. Orton, and P. P. Tamburini. 1982. Cytochrome P-450 induction by clofibrate. Biochem. J. 203:161-168.

37. Mimouni, V., E. N. Christiansen, J. P. Blond, L. Ulmann, J. P. Poisson, and J. Bezard. 1991. Elongation and desaturation of arachidonic acid and eicosapentanoic acid in rat liver. Effect of clofibrate feeding. Biochim. Biophys. Acta. 1086:349-353.

38. Sanchez, R. M., M. Vinals, M. Alegret, M. Vazquez, T. Adzet, M. Merlos, and J. C. Laguna. 1992. Inhibition of rat liver microsomal fatty acid chain elongation by gembrozil in vitro. FEBS (Fed. Eur. Biochem. Soc.) Lett. 300:89-92.

39. Kawashima, Y., K. Musoh, and H. Kozuka. 1990. Peroxisome proliferators enhance linoleic acid metabolism in rat liver. J. Biol. Chem. 265:9170-9175.

40. Borlakoglu, J. T., J. D. Edwards-Webb, and R. R. Dils. 1991. Evidence for the induction of fatty acid desaturation in proliferating hepatic endoplasmic reticulum in response to treatment with polychlorinated biphenyls: are fatty acid desaturates cytochrome P-450-dependent monooxygenases? Int. J. Biochem. 23:925-931.

41. Wang, R. W., P. H. Kari, A. Y. H. Lu, P. E. Thomas, F. P. Guengerich, and K. P. Vyas. 1991. Biotransformation of lovastatin. Arch. Biochem. Biophys. 290:355-361.

42. Mercenne, F., H. Goudonnet, J. Mounie, A. Escousse, and R. C. Truchot. 1991. Effects of simvastatin, a lipoprotein-lowering drug, on the hepatic enzymes involved in drug metabolism in the Wistar rat. Xenobiotica. 21:859-864.

43. Pan, H. Y., A. R. DeVault, D. Wang-Iverson, E. Ivashkiv, B. N. Swanson, and A. A. Sugerman. 1990. Comparative pharmacokinetics and pharmacodynamics of pravastatin and lovastatin. J. Clin. Pharmacol. 30:1128-1135. 